として，最残像解析用ファントムが示された。

演題 187: 可動絞り装置に濃度補償附加フィルタを取 り付け，より診断可能濃度域の桩大をはかったすのであ る. これらの研究については，多くの発表が見られるが， 発表者の施設に利いて最適な方法として選ばれたのであ ろう. とれら附加つィルタについては工作上の問題, 個

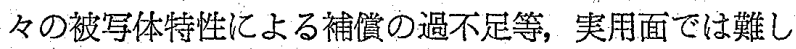
い問題を含んでいるが，夹々に対応し得る形状のものを 製作して扰く事が必要であるう，九州厚生年金病院では， 硬質塩化ビニールにより製作し良い結果を得ている事が 追加された。

演題番号 188: エックス線グリッドを新しい考え方で 試作実験した結果の発表であるが，未だ基礎的な問題の 検討中であり今後の研究に待ちたい; 小监撮影の場合で グリッドを使用したい場合，あるいは 2 方向同時抎大撮 影の場合等, 低格子比のあのが必要と考えられる時に有 効かどうか研究していただきたい，尚，散乱線附加率の 測定方法について問題提起（石川県立; 遠藤広志, 帝京 大；小川敬寿）がなされ，撮影技術委員会において検討 する様お願ししたい.

演題番号 189: 可動絞りの固有ろ過について 測定した 結果, メーカによりアルミニウム当量が一定でない事, JIS による測定方法の不備等が指摘されてりる。 やはり エックス線総ろ過值の観点からエックス線管装置の固有 ろ過值と可動絞りの固有ろ過值との測定は統一されるべ きであり，今後，JIS，委員会に和いて検討を要するもの である.

\section{診断装置 3}

\section{$\mathbf{X}$ 線管他}

座長 三代，忠 (独協大学)

190. ヒートセンサ付大容量回転陽極 $X$ 線管

東京芝浦電気株式会社電子事萆部 ○植村 敬 - 山村俊夫 ·村木 威

循環器彩断, 特にシネ撮影孔適したX線管装置しして 大容量高速回転X線管装置を開発した. 值径 $100 \mathrm{~mm}$ で400kHUの陽極熱容量を持う大形ターゲットを採用 するとともにターゲットの裏面を黒化するととにより， 1, $180 \mathrm{~W}$ の最大陽極冷却率を得て, 1 カット当りの入力 を增し，カット間隔を大幅に短縮することができた。し

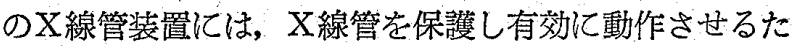
め，陽極温度を直接測定するヒートセンサを使った陽極 温度監視機構を設けた。ターゲットからの赤外線放射を ライトガイドで赤外線検出部へ導き電気信号に変える方 式により，X線管陽極の温度を安定に監視でさるように
なった。

\section{CTスキャナ用 $\mathrm{X}$ 線管装置について}

島津製作所医用技術部

○吉村公男・神戸邦治

CTスキャナ用のX線管装置にあっては，X線出力の 堌大と機械的に強いことが要求される。我々は, X線管 を回転，並進運動によって生ずる遠心力および振動に耐 える保持機構にするとともに，固定陽極形（頭部用）に おいては，陽極を噴油流によって冷却する方法を採用し， 焦点 $1.8 \times 14 \mathrm{~mm}, 130 \mathrm{kV} 30 \mathrm{~mA}$ 連続の定格を，安た， 回転陽極形（全身用）においては，円板ターゲッ卜睘面 に高愊射材をコーティングするととによって，焦点 1.5 $\mathrm{mm}, 40$ 万 HU の定格を有するX線管装置を開発した. 尚，CT スキャナ用X線管装置は，さらにX線出力の增 大が望まれているので，現在性能向上のための努力を継 続中である。

\section{X線シネ撮影における $\mathrm{X}$ 線管の蓄積熱量及び撮影 時間の表示}

自津製作所医用技術部

○坂本五朗・中西 猛・土并泰敬

X線シネ撮影において，高品位の画䆩を得るためには 大電流化低電庄撮影が好ましい。一方X線管定格より大 電流化は無配慮に選定できないし，カット数に応じて適 切な撮影のインターバルをとる必要がある。該適切なイ ンターバルをX線管定格より算出し，かつ操作を行って ゆくのは煩しい，筆者らは使用時点でのX線管 HU值を 自動的に算出し，陽極最大蓄積熱容量よりとれから行な う撮影条件でどれ位の撮影時間が可能かの表示をするて とにより，操作者がX線管負荷のととを考えずに高品位 の画質を得るととにのみ專念できるX線シネ撮影システ ムを開発した。

\section{X線テレビ装置に小焦点管球を用いた時の問題点} について

名古屋大学医学部附属病院放射線部

○伊藤謙助・中島地康・平野泰造

〔目的】オーバチューブX線テレビ装置は一般に大焦 点を用いているためX線写真の画質が㭧い。そこで， 3 倍回転 $(0.8 \times 0.8 \mathrm{~mm})$ 管球を用いた時の問題点につい て検討を加えた。

[実験方法及び結諭] 総合レスポンスを求めることに より画質の判定を行った，小焦点にするととにより 1.5 $\mathrm{lp} / \mathrm{mm}$ の点で 0.1 レスポンスは良くなる.3 倍回転に よる起動時間の延長が考えられるが 2.1 秒であり総合的 亿判㴊すると問題とならない。撮影台の状態（立位加卧 